UDK $577.1: 61$

ISSN 1452-8258

\title{
DETECTION OF LIPOPROTEIN X (LPX) - A CHALLENGE IN PATIENTS WITH SEVERE HYPERCHOLESTEROLAEMIA
}

\author{
OTKRIVANJE LIPOPROTEINA X (LpX) - IZAZOV KOD PACIJENATA \\ SA TEŠKOM HIPERHOLESTEROLEMIJOM
}

\author{
Agnieszka Ćwiklińska1 , Agnieszka Mickiewicz², Robert Kowalski ${ }^{3}$, Barbara Kortas-Stempak ${ }^{1}$, \\ Agnieszka Kuchta1, Krzysztof Mucha ${ }^{4,5}$, Michał Makowiecki ${ }^{6}$, Anna Gliwińska1, Krzysztof \\ Lewandowski ${ }^{7}$, Leszek Pączek ${ }^{4,5}$, Marcin Fijałkowski ${ }^{2}$, Marcin Gruchała ${ }^{2}$, Maciej Jankowski ${ }^{1}$ \\ ${ }^{1}$ Department of Clinical Chemistry, Medical University of Gdansk, Gdansk, Poland \\ $21^{\text {st }}$ Department of Cardiology, Medical University of Gdansk, Gdansk, Poland \\ ${ }^{3}$ Hospital Pharmacy of the University Clinical Centre, Medical University of Gdansk, Gdansk, Poland \\ ${ }^{4}$ Department of Immunology, Transplantology and Internal Medicine, Transplantation Institute, \\ Medical University of Warsaw, Warsaw, Poland \\ 5 Institute of Biochemistry and Biophysics, Polish Academy of Sciences, Warsaw, Poland \\ ${ }^{6}$ Central Laboratory of the University Clinical Centre, Medical University of Gdansk, Gdansk, Poland \\ ${ }^{7}$ Department of Laboratory Medicine, Medical University of Gdansk, Gdansk, Poland
}

\section{Summary}

Background: Lipoprotein $X(L p X)$ is an abnormal lipoprotein fraction, which can be detected in patients with severe hypercholesterolaemia and cholestatic liver disease. LpX is composed largely of phospholipid and free cholesterol, with small amounts of triglyceride, cholesteryl ester and protein. There are no widely available methods for direct measurement of $L p X$ in routine laboratory practice. We present the heterogeneity of clinical and laboratory manifestations of the presence of LpX, a phenomenon which hinders LpX detection.

Methods: The study was conducted on a 26-year-old female after liver transplantation (LTx) with severely elevated total cholesterol (TC) of $38 \mathrm{mmol} / \mathrm{L}$ and increased cholestatic liver enzymes. TC, free cholesterol (FC), cholesteryl esters (CE), triglycerides, phospholipids, HDL-C, LDL-C, and apolipoproteins $\mathrm{Al}$ and $\mathrm{B}$ were measured.

\section{*equal contribution}

Address for correspondence:

Agnieszka Ćwiklińska,

Department of Clinical Chemistry,

Medical University of Gdańsk, Dębinki 7, 80-211 Gdańsk, Poland Tel: +48583492795, Fax: +48583461538

e-mail: agnieszka.cwiklinska@gumed.edu.pl

\section{Kratak sadržaj}

Uvod: Lipoprotein X (LpX) je patološka frakcija lipoproteina koja se može naći kod pacijenata sa teškom hiperholesterolemijom i holestatskih oboljenja jetre. LpX se uglavnom sastoji od fosfolipida i slobodnog holesterola, sa malim količinama triglicerida, estara holesterola i proteina. Ne postoje metode za direktno merenje LpX u rutinskoj laboratorijskoj praksi. Ovde je prikazana heterogenost kliničkih i laboratortijskih manifestacija prisustva LpX, fenomena koji ometaju otkrivanje LpX.

Metode: Izučavanje je izvedeno na 26 -godišnjoj ženi posle transplantacije jetre (LTx) sa izrazito povećanim ukupnim holesterolom (TC) vrednosti $38 \mathrm{mmol} / \mathrm{L}$ i holestatskim jetrenim enzimima, a mereni su i TC, slobodni holesterol (FC), holesteril estri (CE), trigliceridi, fosfolipidi, HDL-C, LDL$\mathrm{C}$ i apolipoproteini Al i B. Izračunati su odnosi TC/apoB i FC:CE.
List of abbreviations: ApoAl, apolipoprotein Al; $\mathrm{ApoB}$ apolipoprotein $B$; ALT, alanine aminotransferase; ALP, alkaline phosphatase; AST, aspartate aminotransferase; CE, cholesteryl ester; CVD, cardiovascular disease; FC, free cholesterol; GGTP, gamma-glutamyl transferase; HDL, high density lipoprotein; $\mathrm{HL}$, hepatic lipase; Hlp, hyperlipoproteinaemia; HoFH, homozygous familial hypercholesterolaemia; LA, lipoprotein apheresis; LCAT, lecithin:cholesterol acyltransferase; LDL, low density lipoprotein; $L T x$, liver transplantation; $L p X$, lipoprotein $X ; P L$, phospholipid; TC, total cholesterol; TG, triglyceride. 
$\mathrm{TC} / \mathrm{apoB}$ and $\mathrm{FC}: \mathrm{CE}$ ratios were calculated. Lipoprotein electrophoresis was performed using a commercially available kit and laboratory-prepared agarose gel.

Results: Commercially available electrophoresis failed to demonstrate the presence of $L p X$. Laboratory-prepared gel clearly revealed the presence of lipoproteins with $\gamma$ mobility, characteristic of $\mathrm{LpX}$. The $\mathrm{TC} / \mathrm{apoB}$ ratio was elevated and the CE level was reduced, confirming the presence of $\mathrm{LpX}$. Regular lipoprotein apheresis was applied as the method of choice in LpX disease and a bridge to reLTx due to chronic liver insufficiency.

Conclusions: The detection of $L p X$ is crucial as it may influence the method of treatment. As routinely available biochemical laboratory tests do not always indicate the presence of LpX, in severe hypercholesterolaemia with cholestasis, any discrepancy between electrophoresis and biochemical tests should raise suspicions of LpX disease.

Keywords: lipoprotein X, severe hypercholesterolaemia, cholestasis, hepatobiliary disorders, electrophoresis

\section{Introduction}

Severe hypercholesterolaemia with a total cholesterol (TC) concentration above $25 \mathrm{mmol} / \mathrm{L}$ $(\sim 1000 \mathrm{mg} / \mathrm{dL})$ is an extremely rare condition. The most widely recognised cause is homozygous familial hypercholesterolaemia $(\mathrm{HoFH})$ presenting with an increased level of LDL-cholesterol (LDL-C) and accelerated advanced cardiovascular disease (CVD) (1). However, severe hypercholesterolaemia may also be unrelated to increased LDL-C, resulting instead from the presence of an abnormal lipoprotein fraction lipoprotein $X(L p X)(2-5)$. LpX is most frequently detected in patients with cholestatic liver disease (6, $7)$ as well as in those with lecithin:cholesterol acyltransferase (LCAT) deficiency, hepatic lipase (HL) deficiency, and after intravenous fat emulsion infusion (6). The LpX was not proved to result in coronary artery disease development $(8,9)$. Moreover, the antioxidative properties of $L p X$ may reduce $L D L$ atherogenicity (8). On the other hand, it has been shown that LpX may be associated with hyperviscosity syndrome and lead to renal disease in cases of LCAT deficiency (10).

LpX takes the form of a spherical particle with a diameter exceeding $30 \mathrm{~nm}$, composed largely of phospholipid (PL) and free cholesterol (FC), with small amounts of triglyceride (TG), cholesteryl ester (CE) and protein, but containing no apolipoprotein $B$ $(a p o B)$. There are no widely available methods for direct measurement of $L p X$ in routine laboratory practice (11). However, due to its chemical composition, patients in whom this lipoprotein is present in serum may exhibit elevated $\mathrm{TC} / \mathrm{apoB}$ and reduced $\mathrm{CE}$ level. The presence of $L p X$ can also be detected using electrophoretic techniques. LpX displays $\gamma$ mobility or moves towards a cathode on agarose gel $(11,12)$. Unfortunately, these analyses are not routinely performed in laboratories.
Izvedena je elektroforeza apolipoproteina primenom komercijalnog kita i agaroza gela koji je pripremljen u laboratoriji. Rezultati: Komercijalnom elektroforezom nije bilo moguće utvrditi prisustvo LpX. Primenom laboratorijski pripremljenog gela utvrđeno je prisustvo lipoproteina čija je pokretljivost odgovarala LpX. Odnos TC/apo B je bio povećan, a nivo CE snižen, što je potvrdilo prisustvo LpX. Lipoproteinska afereza je primenjena kao metoda izbora za oboljenja sa $L p X$ i vezu sa relLTx usled hronične insuficijencije jetre.

Zaključak: Za otkrivanje LpX veoma je važan izbor metode. $\mathrm{S}$ obzirom da rutinski raspoloživi biohemijski laboratorijski testovi uvek ne ukazuju na prisustvo LpX u teške hiperholesterolemije sa holestazom, bilo koja razlika između eketroforeze i biohemijskih testova treba da ukaže na sumnju da postoji LpX oboljenje.

Ključne reči: lipoprotein $X$, teška hiperholesterolemija, holestaza, hepatobilijarno oboljenje, elektroforeza

In this paper, we present the heterogeneity of clinical and laboratory manifestations of the presence of lipoprotein X (LpX), a phenomenon which can hinder $L p X$ detection and diagnosis. We also present the potential for the use of different biochemical tests and agarose electrophoretic techniques to detect LpX, taking into account our experiences and reports from the literature.

\section{Materials and Methods}

The study was undertaken on a 26-year-old female with severely elevated TC above $25 \mathrm{mmol} / \mathrm{L}$ and increased cholestatic liver enzymes.

A peripheral blood sample was taken using commercially available test tubes following overnight fasting. The following biochemical parameters were assessed: lipid parameters (TC, TG, HDL-C, LDL-C, $\mathrm{FC}, \mathrm{CE}$, and $\mathrm{PL})$, apolipoproteins $\mathrm{Al}$ and $\mathrm{B}$, liver parameters (AST, ALT, GGT, ALP, and bilirubin), glucose, creatinine and INR (Table I). For each analyte, the assay was performed according to the manufacturer's instructions.

Lipoprotein electrophoresis was performed using a commercially available electrophoresis kit (Hydragel Lipo+Lp(a), Sebia, France), and with the use of laboratory-prepared agarose gel electrophoresis. The electrophoresis using the commercially available kit was carried out according to the manufacturer's instructions. The laboratory-prepared electrophoresis was performed as follows: aliquots of $10 \mu \mathrm{L}$ of serum were loaded on agarose gel $(0.75 \%$ $(\mathrm{w} / \mathrm{v}))$ and electrophoresed for 75 minutes at $160 \mathrm{~V}$ using a $100 \mathrm{mmol} / \mathrm{L}$ Tris-barbital buffer, $\mathrm{pH}$ 9.3. After separation, the lipoproteins were visualized by staining with Sudan Black B (1\%, (w/v)). 
Table I Methodology of biochemical parameters.

\begin{tabular}{|c|c|c|c|}
\hline Parameter & Method & Reagent manufacturer & Analyser \\
\hline Apolipoprotein Al (apo Al) & immunonephelometry & $\begin{array}{c}\text { Siemens Healthcare GmbH } \\
\text { (Germany) }\end{array}$ & BN II System \\
\hline Apolipoprotein B (apo B) & immunonephelometry & $\begin{array}{c}\text { Siemens Healthcare GmbH } \\
\text { (Germany) }\end{array}$ & BN II System \\
\hline Alanine aminotransferase (ALT) & NADH (without P-5'-P) & Abbott Laboratories (USA) & Architect c8000 \\
\hline Alkaline phosphatase (ALP) & p-nitrophenol & Abbott Laboratories (USA) & Architect c8000 \\
\hline Aspartate aminotransferase (AST) & NADH (without P-5'-P) & Abbott Laboratories (USA) & Architect c8000 \\
\hline Total bilirubin & diazonium salt & Abbott Laboratories (USA) & Architect c8000 \\
\hline Cholesteryl ester (CE) & \multicolumn{3}{|c|}{ calculated as the difference between TC and FC } \\
\hline Creatinine & enzymatic & Abbott Laboratories (USA) & Architect c8000 \\
\hline Free cholesterol (FC) & CHOD-PAP & $\begin{array}{c}\text { Greiner Laboratories GmbH } \\
\text { (Germany) }\end{array}$ & MultiScan Go \\
\hline $\begin{array}{l}\text { Gamma-Glutamyl Transferase } \\
\text { (GGT) }\end{array}$ & $\begin{array}{l}\text { L-Gamma-glutamyl-3- } \\
\text { carboxy-4-nitroanilide }\end{array}$ & Abbott Laboratories (USA) & Architect c8000 \\
\hline Glucose & hexokinase/G6PD & Abbott Laboratories (USA) & Architect c8000 \\
\hline HDL-cholesterol (HDL-C) & $\begin{array}{l}\text { direct (Accelerator } \\
\text { Selective Detergent) }\end{array}$ & Abbott Laboratories (USA) & Architect c8000 \\
\hline INR & coagulometric & $\begin{array}{c}\text { Siemens Healthcare GmbH } \\
\text { (Germany) }\end{array}$ & BCS XP System \\
\hline LDL-cholesterol (LDL-C) & \multicolumn{3}{|c|}{ calculated from the Friedewald formula } \\
\hline Sodium & Indirect ISE & Abbott Laboratories (USA) & Architect c8000 \\
\hline Phospholipid (PL) & choline oxidase-DAOS & $\begin{array}{c}\text { Wako Pure Chemical Industries } \\
\text { (Japan) }\end{array}$ & MultiScan Go \\
\hline Total cholesterol (TC) & CHOD-PAP & Abbott Laboratories (USA) & Architect c8000 \\
\hline Triglyceride (TG) & GPO & Abbott Laboratories (USA) & Architect c8000 \\
\hline
\end{tabular}

\section{Results}

A 26-year-old female patient was admitted to the Cardiology Department of the Medical University of Gdansk with a diagnosis of severe hypercholesterolaemia complicated by ischaemic central retinal vein occlusion, with vision loss. Physical examination revealed signs of jaundice. Corneal arcus and xanthomas were not present. Checking for hypercholesterolaemia and premature atherosclerotic disease in the family history yielded negative results. The patient's medical history revealed diabetes type 1 and autoimmune hepatitis, diagnosed at the age of 14. At that time, the TC level remained within the normal range $(4 \mathrm{mmol} / \mathrm{L})$. Rapidly progressing hepatic failure had resulted in a liver transplantation (LTx) at the age of 16. However, following 6 years of stability, a gradual deterioration of liver function and an increase in lipid parameters were observed. A liver biopsy revealed the rejection of the donor liver. Prednisone (10 mg daily) and cyclosporine (300 mg daily) were administered, with a good response. Nevertheless, a continued increase in TC was observed, even though a rosuvastatin (15 mg daily) and ezetimibe (10 mg daily) were prescribed.
Upon admission to our Centre, laboratory findings showed an exceptionally high concentration of TC (38 mmol/L). The TG level had increased to 6.2 $\mathrm{mmol} / \mathrm{L}$; HDL cholesterol (HDL-C) remained within the normal range. Serum biochemical analysis also showed significantly elevated levels of liver enzymes (Table II). The result of mutational analysis of the LDLR, APOB and PCSK9 genes was negative. Due to a history of elevated liver enzymes, refractoriness to maximally tolerated lipid-lowering medications, and severe hypercholesterolaemia, lipoprotein apheresis (LA) by the lipoprotein filtration technique was initiated. Four courses of LA within an eight-day period reduced TC concentration to $3.8 \mathrm{mmol} / \mathrm{L}$. Subsequent regular biweekly apheresis treatments resulted in a steady state with pre-apheresis TC and LDL-C levels remaining in the ranges 15.5-20.7 and 5.2$10.4 \mathrm{mmol} / \mathrm{L}$, respectively. However, there was no improvement in serum liver enzymes, which indicated a persistent cholestatic liver dysfunction. Thus, we undertook a series of additional lipid tests.

A commercially available agarose electrophoresis set failed to demonstrate the presence of $L p X$. 
Table II Laboratory parameters at admission and following treatment.

\begin{tabular}{|l|c|c|c|}
\hline Parameter & At admission & After treatment & Reference values \\
\hline TC, mmol/L & 38.0 & 8.7 & $<4.9$ \\
\hline TG, mmol/L & 6.2 & 2.6 & $>1.7$ \\
\hline HDL-C, mmol/L & 1.2 & 0.3 & $>1.0$ (male) \\
\hline LDL-C, mmol/L & not calculated & 7.2 & $<3.0$ \\
\hline AST, U/L & 216 & 244 & $5-34$ \\
\hline ALT, U/L & 297 & 196 & $<55$ \\
\hline GGT, U/L & 4104 & 1035 & $9-36$ \\
\hline ALP, U/L & 2209 & 1601 & $40-150$ \\
\hline Total bilirubin, $\mu \mathrm{mol} / \mathrm{L}$ & 90.3 & 314.5 & $1.7-20.4$ \\
\hline eGFR-MDRD & $>60$ & 47 & $>60$ \\
\hline Sodium, mmol/L & 131 & 136 & $136-145$ \\
\hline Glucose, mmol/L & 3.9 & 5.3 & $<5.6$ \\
\hline INR & 1.01 & 1.1 & $0.9-1.3$ \\
\hline
\end{tabular}

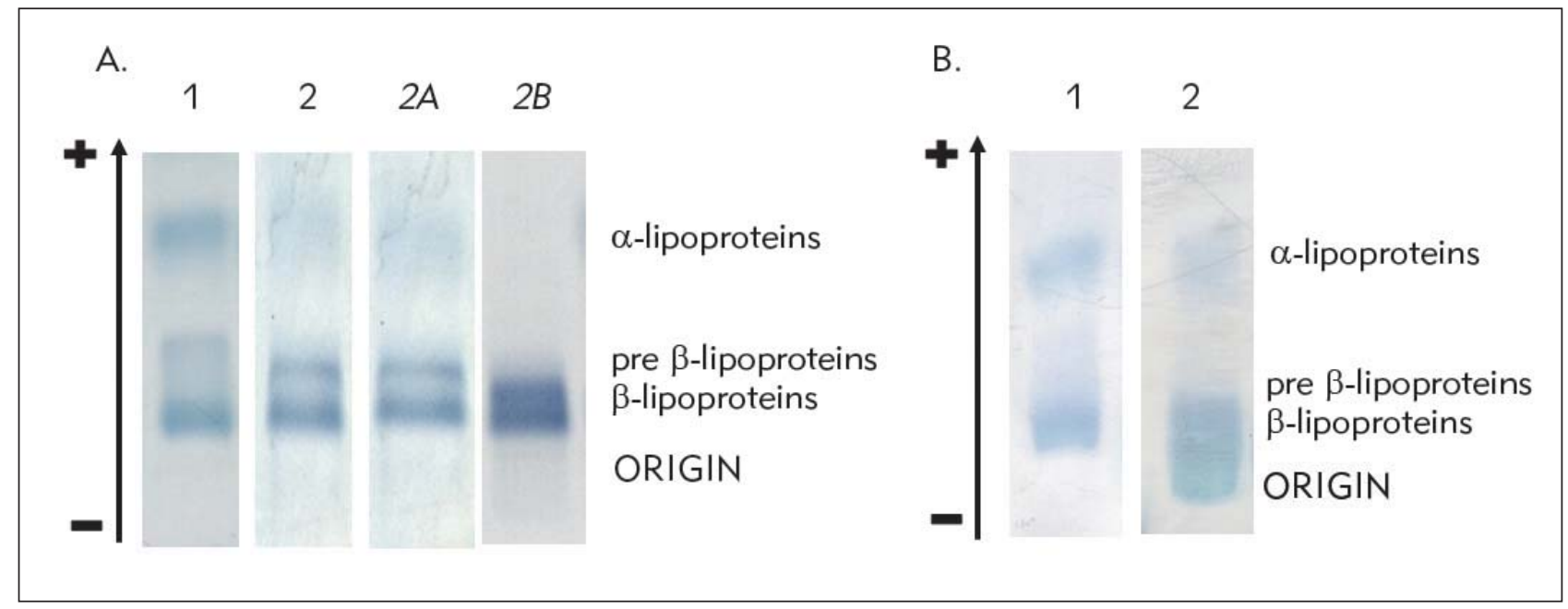

Figure 1 Serum lipoprotein profile obtained using a commercially available electrophoresis kit (A), and laboratory-prepared electrophoresis set $(\mathrm{B}) .1$ - control sample; 2 - sample from the patient. $2 \mathrm{~A}$ - analysis of a sample obtained from the patient two months after detection of LpX (lipid profile parameters: TC, $17.2 \mathrm{mmol} / \mathrm{L} ; \mathrm{TG}, 2.4 \mathrm{mmol} / \mathrm{L} ; \mathrm{HDL}-\mathrm{C}, 0.6 \mathrm{mmol} / \mathrm{L}$; LDL-C, 15.5 $\mathrm{mmol} / \mathrm{L}$ ); $2 B$ - analysis of a sample obtained from the patient one year after detection of $\mathrm{LpX}$ (lipid profile parameters: TC, 19.2 $\mathrm{mmol} / \mathrm{L} ; \mathrm{TG}, 7.0 \mathrm{mmol} / \mathrm{L} ; \mathrm{HDL}-\mathrm{C}, 0.3 \mathrm{mmol} / \mathrm{L}$; LDL-C, not calculated). A subtle fraction with $\gamma$ mobility was observed only in $2 B$ analysis.

Intense staining of the $\beta$ - and pre- $\beta$-mobility areas, characteristic of LDL and VLDL, respectively, was observed, indicating hyperlipoproteinaemia (HIp) type IIb, and no fraction was observed in the start area (Figure 1A, lane 2). Conversely, a laboratory-prepared agarose electrophoresis set showed a clearly visible fraction with $\gamma$ mobility and the green tinge characteristic of LpX (Figure 1B, lane 2). The biochemical analysis revealed very high $\mathrm{PL}$ and $\mathrm{FC}$ levels. The CE level was significantly lower than reference values whereas the $\mathrm{TC} / \mathrm{apoB}$ ratio was significantly higher (Table III).

The results of laboratory-prepared electrophoresis and biochemical analysis clearly revealed the presence of $L p X$ in the sample. Its detection focused our efforts on investigating the hepatobiliary causes of severe hypercholesterolaemia. Magnetic resonance revealed stenosis of the biliary tract and a subsequent stent implantation was performed, resulting in slight 
Table III Lipid and apolipoprotein analysis in the course of LpX detection.

\begin{tabular}{|c|c|c|}
\hline Parameter & & Reference values \\
\hline \multicolumn{3}{|c|}{ Lipid profile } \\
\hline $\mathrm{TC}, \mathrm{mmol} / \mathrm{L}$ & 21.2 & $<4.9$ \\
\hline $\mathrm{TG}, \mathrm{mmol} / \mathrm{L}$ & 4.1 & $<1.7$ \\
\hline $\mathrm{HDL}-\mathrm{C}, \mathrm{mmol} / \mathrm{L}$ & 0.9 & $\begin{array}{l}>1.2 \text { (female) } \\
>1.0 \text { (male) }\end{array}$ \\
\hline LDL-C, mmol/L & 18.4 & $<3.0$ \\
\hline \multicolumn{3}{|c|}{ Apolipoproteins } \\
\hline ApoAl, g/L & 1.16 & \\
\hline ApoB, g/L & 1.92 & \\
\hline \multicolumn{3}{|c|}{ Additional lipid analysis } \\
\hline $\mathrm{PL}, \mathrm{mmol} / \mathrm{L}$ & 23.6 & \\
\hline $\mathrm{FC}, \mathrm{mmol} / \mathrm{L}$ & 18.8 & \\
\hline $\mathrm{CE}, \mathrm{mmol} / \mathrm{L}$ & 2.4 & \\
\hline FC:CE & $1: 0.13$ & $\sim 1: 2^{*}$ \\
\hline $\mathrm{TC} / \mathrm{apoB}, \mathrm{mmol} / \mathrm{g}$ & 11.0 & $\begin{array}{c}4.0-7.7 \text { (female) } \\
3.8-6.3 \text { (male) }\end{array}$ \\
\hline
\end{tabular}

*according to (11)

improvement of cholestatic parameters. Repeated liver biopsies, along with laboratory and imaging tests, led to a diagnosis of chronic liver insufficiency of a complex nature. The patient was placed on the liver transplantation list and referred back to $L A$ as a bridge to re-LTx. After two and a half years of biweekly apheresis therapy, the patient's condition deteriorated rapidly secondary to the development of septic shock followed by sudden death.

\section{Discussion}

We report the heterogeneity of clinical and laboratory manifestations of $\mathrm{LPX}$ which can hinder its detection, especially if only routinely available laboratory tests are used.

Differentiation of severe hypercholesterolaemia caused by elevated LDL-C and related to the presence of LpX is important, as it may influence the method of treatment. Although oral lipid-lowering medications are the first-line treatment in hypercholesterolaemia caused by increased LDL-C, they are insufficient and hazardous in LpX disease with coexisting hepatocellular injury. It has been shown that LpX can be safely and efficiently removed by plasma exchange and selective LA, resulting in an improvement of clinical symptoms and normalization of lipid parameters (13). Regarding the cardiovascular risk in both LDL-C and LpX accumulation, it is clear that increased LDL-C levels lead to accelerated atherosclerosis. Available data on cardiovascular risk in LpX disease are not consistent and further large studies are needed $(14,15)$. Nevertheless, it has been proved that $\mathrm{LpX}$ accumulation leads to hyperviscosity syndrome. In our described patient, hyperviscosity syndrome resulted in a central retinal vein thrombosis and vision loss (16).

In the case of our patient, LpX detection convinced us that regular bi-weekly apheresis by cascade filtration is the only efficient and safe therapy, as previously described by other authors (17). We observed a high degree of efficacy of TC removal in LA sessions. Furthermore, the $L p X$ detection directed our attention towards the hepatobiliary causes of hypercholesterolaemia. Prior to that, we had suspected that the patient might have received a liver from a donor with undiagnosed familial hypercholesterolaemia. Nevertheless, further biliary tract stenting failed to improve cholestatic parameters and lipid levels. Liver transplantation remained the only possible method of correcting the underlying liver pathology.

Detection of $L p X$ is also crucial since it can interfere with a number of biochemical tests. For instance, LDL-C calculated using the Friedewald formula is invalid in the presence of $L p X$, since this equation can be used only if three lipoprotein fractions, VLDL, LDL, and $\mathrm{HDL}$ are present in serum. Moreover, LpX can interfere with direct LDL-C assays, the degree of interference being dependent on the method used (18). There is also evidence that LpX can interfere with the measurements of apolipoprotein $\mathrm{E}$ phenotype analysis (19), serum total protein (20), and electrolytes, causing pseudohyponatremia, pseudohypokalemia, and pseudohypochloremia, in cases where indirect ion-selective electrodes are used (21-24).

Widely available methods for the direct measurement of $L p X$ in routine laboratory practice are lacking (11). However, there are some laboratory methods capable of providing evidence of the presence of LpX. Agarose electrophoresis is considered one of these (11). Unfortunately, in our study a commercially available agarose electrophoresis set failed to clearly demonstrate the presence of $L p X$. Moreover, the presence of $L p X$ manifested itself in different ways in electrophoresis. In the case of our patient, the fraction with mobility lower than $\beta$ was not detected in two electropherograms, whereas only a subtle smearing band with $\gamma$ mobility was observed in the third one, performed one year later (Figure $1 A$, lane $2 B$ ). In most studies, co-migration of $L p X$ with $\beta$ mobility lipoproteins (LDL) was observed, with eventually subtle reverse migration in the LDL region (14, $22,23,25,26)$. Phatlhane et al. (3), in the case of a patient with $L p X$, observed intense staining in the $\beta$ area, with minor cathodic migration and a slight green tinge. Less frequently, $L p X$ has been observed 
at the site of origin, suggesting the presence of chylomicrons $(19,27)$ or as a smearing lipoprotein band with slow migration (18).

Unlike commercial electrophoresis kits, our laboratory-prepared electrophoresis set clearly demonstrated an additional fraction with $\gamma$ mobility and the green tinge characteristic for particles rich in PL. The applied buffer, which we had previously used in our study with phosphatidylcholine liposomes and $\gamma$ mobility lipoproteins (28), enabled clear differentiation of particles with low electrophoretic mobility. A clear demonstration of the presence of $L p X$ was also presented by Inamoto et al. (29), who applied cholesterol and triglyceride staining following lipoprotein electrophoresis. Other electrophoretic techniques have also been used to detect LpX, for example nondenaturing polyacrylamide gradient gel electrophoresis revealed the presence of $L p X$ as particles in the intermediate region of size and with a narrower range of sizes than VLDL (3). In Quantimetrix Lipoprint LDL subfraction analysis, LpX was detected as a large band between the loading and separation gels, since LpX particles are too large to enter 3\% polyacrylamide gel (25). Taking into account our report as well as those of others, it can be concluded that the presence of LpX manifests in different ways in electrophoresis, in a patient, and in an applied electrophoresis set dependent manner. Thus, the agarose electrophoresis results obtained in routine laboratory testing concerning patients with severe hypercholesterolaemia should be analysed very carefully. Eventually, other electrophoretic techniques or methods, such as ultracentrifugation, nuclear magnetic resonance spectroscopy, and immunological analysis, may be useful for LpX detection (6). Unfortunately, these methods are usually available only in specialised laboratories, reducing the potential for their use in routine practice. However, it has been shown that the presence of LpX can also be indicated using biochemical tests such as FC and PL levels, as well as FC:CE and TC/apoB ratios. Among these, the most readily available in routine practice seems to be the last named (6). LpX contains cholesterol but not apoB; thus, $T C / a p o B$ ratios are increased in patients with $L p X$. Reference values for $T C / a p o B$ ratios have been developed, and significantly increased $\mathrm{TC} / \mathrm{apoB}$

\section{References}

1. Cuchel M, Bruckert E, Ginsberg HN, Raal FJ, Santos RD, Hegele RA, et al. Homozygous familial hypercholesterolaemia: new insights and guidance for clinicians to improve detection and clinical management. A position paper from the Consensus Panel on Familial Hypercholesterolaemia of the European Atherosclerosis Society. Eur Heart J 2014; 35: 2146-57.

2. Jankowski K, Wyzgal A, Wierzbicka A, Tronina O, Durlik M, Pruszczyk P. Rapid normalization of severe hypercho- ratios have been observed in many patients with $L p X$ $(13,19,22,25-27,30)$. As well, in our patient the TC/apoB ratio was significantly increased. However, an only slightly increased TC/apoB ratio may be related to the co-existence of LpX with LDL, which occurs in some patients (7). In these patients, the apoB level is increased, lowering the $\mathrm{TC} / \mathrm{apoB}$ ratio, sometimes even to established reference values (6), as observed in the patient with LpX described by Sivakumar et al. (21). Thus, it can be concluded that $\mathrm{TC} / \mathrm{apoB}$ ratios, along with other biochemical analyses such as FC:CE ratio, do not always directly indicate the presence of LpX, making the detection of this lipoprotein difficult.

Thus, taking into account the heterogeneity of laboratory manifestations of the presence of $L p X$ in plasma, we conclude that, in routine practice, any abnormalities in electrophoresis or discrepancies between electrophoresis and lipid-related biochemical tests (i.e. between electrophoresis and TG level or between $\mathrm{TC}$ and apoB levels) should be analysed very carefully and should raise suspicions of the presence of LpX, especially in hypercholesterolaemic patients with cholestasis.

\section{Ethics}

All procedures were in accordance with the ethical standards of the Helsinki declaration.

The analysis was performed using material obtained from the patient during hospitalization for diagnostic purposes, and informed consent was previously given for the scope of treatment. The patient gave oral consent to publication in the presence of two witnesses. Due to the patient's death, written informed consent to publication has been obtained from the closest relative, the patient's mother.

Acknowledgements. This work was supported by the Medical University of Gdansk grants no. ST 020125/07/524 and ST 02-0085/07/182.

\section{Conflict of interest statement}

The authors stated that they have no conflicts of interest regarding the publication of this article.

lesterolemia mediated by lipoprotein $\mathrm{X}$ after liver transplantation in a patient with cholestasis - a case report. Acta Biochim Pol 2015; 62: 621-3.

3. Phatlhane DV, Zemlin AE. Severe hypercholesterolemia mediated by lipoprotein $\mathrm{X}$ in a patient with cholestasis. Ann Hepatol 2015; 14: 924-8.

4. Turchin A, Wiebe DA, Seely EW, Graham T, Longo W, Soiffer R. Severe hypercholesterolemia mediated by 
lipoprotein $X$ in patients with chronic graft-versus-host disease of the liver. Bone Marrow Transplant 2005; 35: 85-9.

5. Soros P, Bottcher J, Maschek H, Selberg O, Muller MJ. Lipoprotein-X in patients with cirrhosis: its relationship to cholestasis and hypercholesterolemia. Hepatology 1998; 28: 1199-205.

6. Crook MA. Lipoprotein X: clinical implications. Ann Clin Biochem 2013; 50: 93-4.

7. Jahn CE, Schaefer EJ, Taam LA, Hoofnagle JH, Lindgren FT, Albers JJ, et al. Lipoprotein abnormalities in primary biliary cirrhosis. Association with hepatic lipase inhibition as well as altered cholesterol esterification. Gastroenterology 1985; 89: 1266-78.

8. Chang PY, Lu SC, Su TC, Chou SF, Huang WH, Morrisett $J D$, et al. Lipoprotein- $X$ reduces $L D L$ atherogenicity in primary biliary cirrhosis by preventing LDL oxidation. J Lipid Res 2004; 45: 2116-22.

9. Longo M, Crosignani A, Battezzati PM, Squarcia Giussani C, Invernizzi P, Zuin $M$, et al. Hyperlipidaemic state and cardiovascular risk in primary biliary cirrhosis. Gut 2002; 51: 265-9.

10. Ossoli A, Neufeld EB, Thacker SG, Vaisman B, Pryor M, Freeman LA, et al. Lipoprotein X Causes Renal Disease in LCAT Deficiency. PLoS One 2016; 11: e0150083.

11. G. Neely RD, Boot CS. Laboratory investigation of lipoprotein X. Clinical Lipidology 2017; 12: 43-4.

12. Fellin R, Manzato E. Lipoprotein-X fifty years after its original discovery. Nutr Metab Cardiovasc Dis 2019; 29: 4-8.

13. Brandt EJ, Regnier SM, Leung EK, Chou SH, Baron BW, $\mathrm{Te} \mathrm{HS}$, et al. Management of lipoprotein $\mathrm{X}$ and its complications in a patient with primary sclerosing cholangitis. Clinical Lipidology 2015; 10: 305-12.

14. Yehya A, Huang R, Bernard DW, Gotto A, Robbins RJ. Extreme hypercholesterolemia in cholestatic sarcoidosis due to lipoprotein X: Exploring the cholesterol gap. J Clin Transl Endocrinol Case Rep 2018; 10: 11-3.

15. Sorokin A, Brown JL, Thompson PD. Primary biliary cirrhosis, hyperlipidemia, and atherosclerotic risk: a systematic review. Atherosclerosis 2007; 194: 293-9.

16. Rosenson RS, Baker AL, Chow MJ, Hay RV. Hyperviscosity syndrome in a hypercholesterolemic patient with primary biliary cirrhosis. Gastroenterology 1990; 98: 1351-7.

17. Heinl RE, Tennant HM, Ricketts JC, Rice CR, Robinson $C B$, Sandesara PB, et al. Lipoprotein- $X$ disease in the setting of severe cholestatic hepatobiliary autoimmune disease. J Clin Lipidol 2017; 11: 282-6.
18. Matsushima K, Sugiuchi $H$, Anraku K, Nishimura $H$, Manabe $M$, Ikeda $K$, et al. Differences in reaction specificity toward lipoprotein $X$ and abnormal LDL among 6 homogeneous assays for LDL-cholesterol. Clin Chim Acta 2015; 439: 29-37.

19. Benjamini Y, Hochberg Y. Controlling the False Discovery Rate - a Practical and Powerful Approach to Multiple Testing. Journal of the Royal Statistical Society Series BMethodological 1995; 57: 289-300.

20. Futatsugi A, Hidaka E, Kubota N, Nishijima F, Yoshizawa $\mathrm{K}$, Ishimine $\mathrm{N}$, et al. Abnormal Serum Total Protein Measurement by Lipoprotein-X in an Infant with Biliary Atresia. Rinsho Byori 2015; 63: 1271-6.

21. Sivakumar T, Chaidarun S, Lee HK, Cervinski M, Comi R. Multiple lipoprotein and electrolyte laboratory artifacts caused by lipoprotein $\mathrm{X}$ in obstructive biliary cholestasis secondary to pancreatic cancer. J Clin Lipidol 2011; 5: 324-8.

22. Hussain I, Ahmad Z, Garg A. Extreme hypercholesterolemia presenting with pseudohyponatremia - a case report and review of the literature. J Clin Lipidol 2015; 9: 260-4.

23. Faroogi MS, Hashim IA. A woman with primary biliary cirrhosis and hyponatremia. Clin Chem 2015; 61: 1028-31.

24. Ravella S, Lefavour GS, Carayannopoulos MO, Parikh A. Hyponatremia in a patient with obstructive jaundice. Kidney Int 2015; 88: 921-2.

25. Foley KF, Silveira MG, Hornseth JM, Lindor KD, McConnell JP. A patient with primary biliary cirrhosis and elevated LDL cholesterol. Clin Chem 2009; 55: 187-91.

26. Chow A, Rifici VA, Schneider SH. Lipoprotein-X in a Patient with Lymphoplasmacytic Sclerosing Cholangitis: An Unusual Cause of Secondary Hypercholesterolemia. AACE Clinical Case Rep 2015; 2: e20-e24.

27. Stepien KM, Divyateja H, Ahmed F, Prinsloo P, Gupta P. Lipoprotein $X$ in a patient with cholestasis and hypertriglyceridaemia. Ann Clin Biochem 2013; 50: 173-5.

28. Cwiklinska A, Kortas-Stempak B, Gliwinska A, Pacanis A, Kuchta A, Wroblewska M. Interaction between VLDL and phosphatidylcholine liposomes generates new gammaLpE-like particles. Lipids 2014; 49: 143-53.

29. Inamoto $Y$, Teramoto T, Shirai $K$, Tsukamoto $H$, Sanda T, Miyamura K, et al. Severe hypercholesterolemia associated with decreased hepatic triglyceride lipase activity and pseudohyponatremia in patients after allogeneic stem cell transplantation. Int J Hematol 2005; 82: 362-6.

30. Suzuki L, Hirayama S, Fukui M, Sasaki M, Hiroi S, Ayaori $M$, et al. Lipoprotein- $X$ in cholestatic patients causes xanthomas and promotes foam cell formation in human macrophages. J Clin Lipidol 2017; 11: 110-8. 